\title{
STUDIES OF GONOCOCCAL INFECTION. III. A COMPARISON OF THE BACTERICIDAL PROPERTIES OF THE SYNOVIAL FLUID AND BLOOD IN GONOCOCCAL ARTHRITIS
}

\author{
By WESLEY W. SPINK AND CHESTER S. KEEFER \\ (From the Thorndike Memorial Laboratory, Second and Fourth Medical Services (Harvard), \\ Boston City Hospital, and the Department of Medicine, Harvard Medical School, Boston)
}

(Received for publication July 13,1937 )

In 1934 (1), the characteristics of the synovial fluid in gonococcal arthritis were defined. It was shown that such synovial fluid had all of the features of an exudate with an elevated protein content, large amounts of mucin, and varying numbers of leukocytes. The non-colloidal electrolytes were of the same concentrations as that of the blood with the exception of the sugar content. In the infected fluids, the sugar was decreased below the level of the blood sugar; in the sterile fluids, it was the same as in the blood. In view of our observation (2) that the blood plasma of most patients with gonococcal infection contained bacteriolytic properties for the gonococcus, the immune bodies in the synovial fluid were studied and compared with that of the blood from the same individual. In this way, we sought an explanation for the sterile synovial fluid in some cases of gonococcal arthritis. In addition, we were interested in determining whether antibodies were present in the same or different titers in the synovial fluid and blood.

\section{MATERIALS AND METHODS}

In a previous paper (3) we demonstrated that the gonococcus was killed in vitro by lysis and that this was due to the combined action of specific antibodies and complement. This view is shared by Gordon and Hoyle (4) who have shown that the destruction of the gonococcus is due to both a heat-stabile and a heat-labile factor. Moreover, we have found that patients with gonococcal infections frequently show an increase in the bactericidal power of the whole blood during the course of the infection, and it is more striking in patients who have metastatic lesions than in those with only local genital infections. There is also some variation in the bactericidal power depending upon the strain of organism employed in the test. In the present studies, homologous organ- isms were used, and the bactericidal tests were carried out in accordance with the methods previously described by us (2). One-half cubic centimeter of blood was used and equivalent amounts of synovial fluid.

The diagnosis of gonococcal arthritis was made by isolating the gonococcus from the synovial fluid in 7 cases. In 21 the synovial fluid was sterile, and in these cases the diagnosis was made by: (1) isolating the gonococcus from the urethra, (2) the presence of positive gonococcal complement-fixation reactions in the blood, and (3) the course of the disease.

Complement was titrated by the usual method. For control observations, bactericidal tests on the blood and synovial fluid were carried out on 12 patients with other types of arthritis.

\section{LITERATURE}

The literature on the presence of antibodies in the fluids of the various body cavities has been thoroughly reviewed by Finland (5) who found that in lobar pneumonia sterile pleural fluids obtained at or about the time of crisis contained antibodies similar to those in the blood serum, while infected fluids did not contain antibodies. In serum-treated cases, horse serum was found in the fluid of both infected and non-infected samples of fluid. There is, thus, evidence that antibodies can diffuse into the pleural cavity from the blood stream, and that they are present especially in sterile effusion.

It has been found that during an inflammation of the joints, antibodies in the form of agglutinins $(6,7)$ can diffuse into the synovial cavities. Longcope (8) has noted horse serum in the synovial fluid of patients with serum sickness, thus demonstrating that foreign protein can likewise diffuse into the joints. We (9) have shown that other substances such as antitryptic ferments 
are present in the synovial fluid in arthritis. It is possible, then, that the presence or absence of organisms in the synovial fluid in gonococcal arthritis is due, in part, to the presence or absence of antibodies.

\section{The bactericidal action of the synovial fluid}

From our previous observations $(2,3)$ on the bacteriolytic activity of the whole blood for the gonococcus, it was evident that destruction of the organism in vitro depended upon the combined action of a heat-stabile and a heat-labile factor. To determine whether the same were true for synovial fluid, we studied the effects of heating synovial fluid of patients with and without bactericidal properties and then adding complement (fresh plasma), immune serum, or both, to the synovial fluid. The immune serum was purchased in the open market and was manufactured by Parke Davis Company. It agglutinated all of the strains of gonococci that were used in the experiments. From Table I, it is obvious that heating actively bactericidal synovial fluid at $56^{\circ} \mathrm{C}$. for 30 minutes destroyed its bactericidal activity. This property could not be restored by the addition of immune serum but could be reactivated by the addition of complement. When synovial fluid which was not actively bactericidal was studied, it could be made active by the addition of immune serum. When such a fluid was heated to $56^{\circ} \mathrm{C}$., however, and immune serum added, it was not possible to demonstrate bactericidal activity unless complement was added at the same time.

These experiments indicate that when the gonococcus is destroyed in vitro by synovial fluid it is necessary to have both complement and antibody present.

Inasmuch as organisms were present in some samples of synovial fluid and not in others, it was conceivable that synovial fluid was a poor culture medium for these organisms. This seemed unlikely, however, in view of the fact that gonococci can be isolated from the synovial fluid in some cases, and when gonococci are added to synovial fluid from patients with non-gonococcal arthritis (Figure 1-C) growth was always observed.

It seemed clear that the bactericidal activity of the synovial fluid could be studied in the same
TABLE I

The bactericidal action of synovial fluid, heated at $56^{\circ} \mathrm{C}$. and unheated, with and without antibody

\begin{tabular}{|c|c|c|c|c|c|c|c|}
\hline & \multicolumn{6}{|c|}{ Dilution of organisms } & \multirow{2}{*}{$\begin{array}{c}\text { Number } \\
\text { of } \\
\text { organisms } \\
1^{-6}\end{array}$} \\
\hline & $10^{-1}$ & $10-2$ & $10^{-3}$ & $30^{-4}$ & $10-8$ & $10-8$ & \\
\hline $\begin{array}{l}\text { Synovial fluid } 0.25 \text { cc. } \\
\text { Organisms } 0.1 \text { cc. }\end{array}$ & + & + & + & + & + & + & 6 \\
\hline $\begin{array}{l}\text { Synovial fluid, heated at } \\
56^{\circ} \mathrm{C} .30 \text { minutes, } 0.25 \mathrm{cc} \text {. } \\
\text { Organisms } 0.1 \mathrm{cc} \text {. }\end{array}$ & + & + & + & + & + & + & 6 \\
\hline $\begin{array}{l}\text { Synovial fluid, unheated, } \\
0.25 \text { cc. } \\
\text { Antigonococal serum } 1: 40 \\
0.1 \text { cc. } \\
\text { Organisms } 0.1 \mathrm{cc} \text {. }\end{array}$ & + & + & $\mathbf{0}$ & 0 & $\mathbf{0}$ & $\mathbf{0}$ & 6 \\
\hline $\begin{array}{l}\text { Synovial fluid, heated, } 0.25 \\
\text { cc. } \\
\text { Antigonococcal serum } 1: 40 \\
\text { 0.1 cc. } \\
\text { Organisms } 0.1 \mathrm{cc} \text {. }\end{array}$ & + & + & + & + & + & + & 6 \\
\hline $\begin{array}{l}\text { Synovial fluid, heated, } 0.25 \\
\text { cc. } \\
\text { Antigonococcal serum } 1: 40 \\
0.1 \text { cc. plus } 0.3 \mathrm{cc} \text {. un- } \\
\text { heated plasma }\end{array}$ & + & + & + & $\mathbf{0}$ & $\mathbf{0}$ & 0 & 6 \\
\hline $\begin{array}{l}\text { Unheated plasma } 0.3 \mathrm{cc} \text {. } \\
\text { Organisms } 0.1 \mathrm{cc} \text {. }\end{array}$ & + & + & + & + & + & + & 6 \\
\hline $\begin{array}{l}\text { Unheated plasma } 0.3 \mathrm{cc} \text {. } \\
\text { Antigonococcal serum } 1: 40 \\
0.1 \text { cc. }\end{array}$ & + & $\mathbf{0}$ & $\mathbf{0}$ & $\mathbf{0}$ & $\mathbf{0}$ & 0 & 6 \\
\hline $\begin{array}{l}\text { Synovial fluid } 0.5 \text { cc. } \\
\text { Organisms } 0.1 \text { cc. }\end{array}$ & + & + & + & + & + & + & 13 \\
\hline $\begin{array}{l}\text { Synovial fluid, heated at } \\
56^{\circ} \mathrm{C} .30 \text { minutes } 0.5 \mathrm{cc} \text {. } \\
\text { Organisms } 0.1 \mathrm{cc} \text {. }\end{array}$ & + & + & + & + & + & + & 13 \\
\hline $\begin{array}{l}\text { Synovial fluid, heated at } \\
56^{\circ} \mathrm{C} .30 \text { minutes, } 0.5 \mathrm{cc} \text {. } \\
\text { Organisms } 0.1 \mathrm{cc} \text {. } \\
\text { Antigonococcal serum } 1: 40\end{array}$ & + & + & + & + & + & + & 13 \\
\hline $\begin{array}{l}\text { Synovial fluid, heated at } \\
56^{\circ} 0.5 \text { cc. } 30 \text { minutes } \\
\text { Organisms } 0.1 \text { cc. } \\
\text { Fresh plasma }\end{array}$ & + & + & + & + & + & + & 13 \\
\hline $\begin{array}{l}\text { Synovial fluid } 0.5 \mathrm{cc} \text {. } \\
\text { Antigonococcal serum } 0.1 \\
\text { cc. } \\
\text { Organisms } 0.1 \mathrm{cc} \text {. }\end{array}$ & + & + & + & $\mathbf{0}$ & $\mathbf{0}$ & $\mathbf{0}$ & 13 \\
\hline $\begin{array}{l}\text { Synovial fluid, heated, } 0.5 \\
\text { cc. } \\
\text { Antigonococcal serum } 0.1 \\
\text { cc. } \\
\text { Organisms } 0.1 \text { cc. } \\
\text { Plasma } 0.1 \text { cc. }\end{array}$ & + & + & + & + & $\mathbf{0}$ & $\mathbf{0}$ & 13 \\
\hline $\begin{array}{l}\text { Synovial fluid } 0.5 \mathrm{cc} \text {. } \\
\text { Organisms } 0.1 \mathrm{cc} \text {. }\end{array}$ & + & 0 & 0 & 0 & 0 & 0 & 3 \\
\hline $\begin{array}{l}\text { Synovial fluid, heated, } 0.5 \\
\text { cc. } \\
\text { Organisms } 0.1 \text { cc. }\end{array}$ & + & + & + & + & + & + & 3 \\
\hline $\begin{array}{l}\text { Synovial fluid, heated, } 0.5 \\
\text { cc. } \\
\text { Organisms } 0.1 \text { cc. } \\
\text { Antigonococcal serum } 0.1 \\
\text { cc. }\end{array}$ & + & + & + & + & + & + & 3 \\
\hline $\begin{array}{l}\text { Synovial fluid, heated, } 0.5 \\
\text { cc. } \\
\text { Organisms } 0.1 \text { cc. } \\
\text { Fresh plasma } 0.3 \text { cc. }\end{array}$ & + & + & + & 0 & 0 & 0 & 3 \\
\hline $\begin{array}{l}\text { Antigonococcal serum } 0.5 \\
\text { cc. } \\
\text { Organisms } 0.1 \mathrm{cc} \text {. }\end{array}$ & + & + & + & + & + & + & 26 \\
\hline $\begin{array}{l}\text { Antigonococcal serum } 0.5 \\
\text { cc. } \\
\text { Organisms } 0.1 \mathrm{cc} \text {. } \\
\text { Fresh plasma } 0.1 \mathrm{cc} \text {. }\end{array}$ & - & - & 0 & 0 & 0 & 0 & 26 \\
\hline
\end{tabular}


way as the blood and that the destruction of the organism was due to the same mechanism as exists in the blood plasma.

Comparison of the bactericidal action of the whole blood and synovial fluid in gonococcal arthritis and controls

To compare the bactericidal action of the whole blood and the synovial fluid from the same individual, bactericidal tests were carried out on a group of 13 cases of non-gonococcal arthritis and a group of 18 cases of gonococcal arthritis. In all, 44 samples of synovial fluid were studied. For purposes of discussion, it is convenient to divide the cases into those with: 1 , infected fluids, 2 , sterile fluids, and 3 , the cases without gonococcal arthritis.

The maximum number of gonococci that could be killed by $0.5 \mathrm{cc}$. of whole blood, and by the same amount of synovial fluid, was determined by the methods described previously. Five-tenths of a cubic centimeter of synovial fluid was used in most cases since it was a convenient amount to work with, but in 4 cases $0.25 \mathrm{cc}$. was used since this amount was comparable to the approximate amount of plasma contained in $0.5 \mathrm{cc}$. of whole blood. The results are shown in Figure 1, and they may now be discussed.

Infected fluid. The results of comparing the bactericidal power of the whole blood and synovial fluid in gonococcal arthritis with infected fluids are shown in Figure $1-A$. There were 7 samples of infected synovial fluid. Gonococci were isolated from all of them. Although the synovial fluid was not capable of killing the organisms, it was found that the blood from the

NO. OF

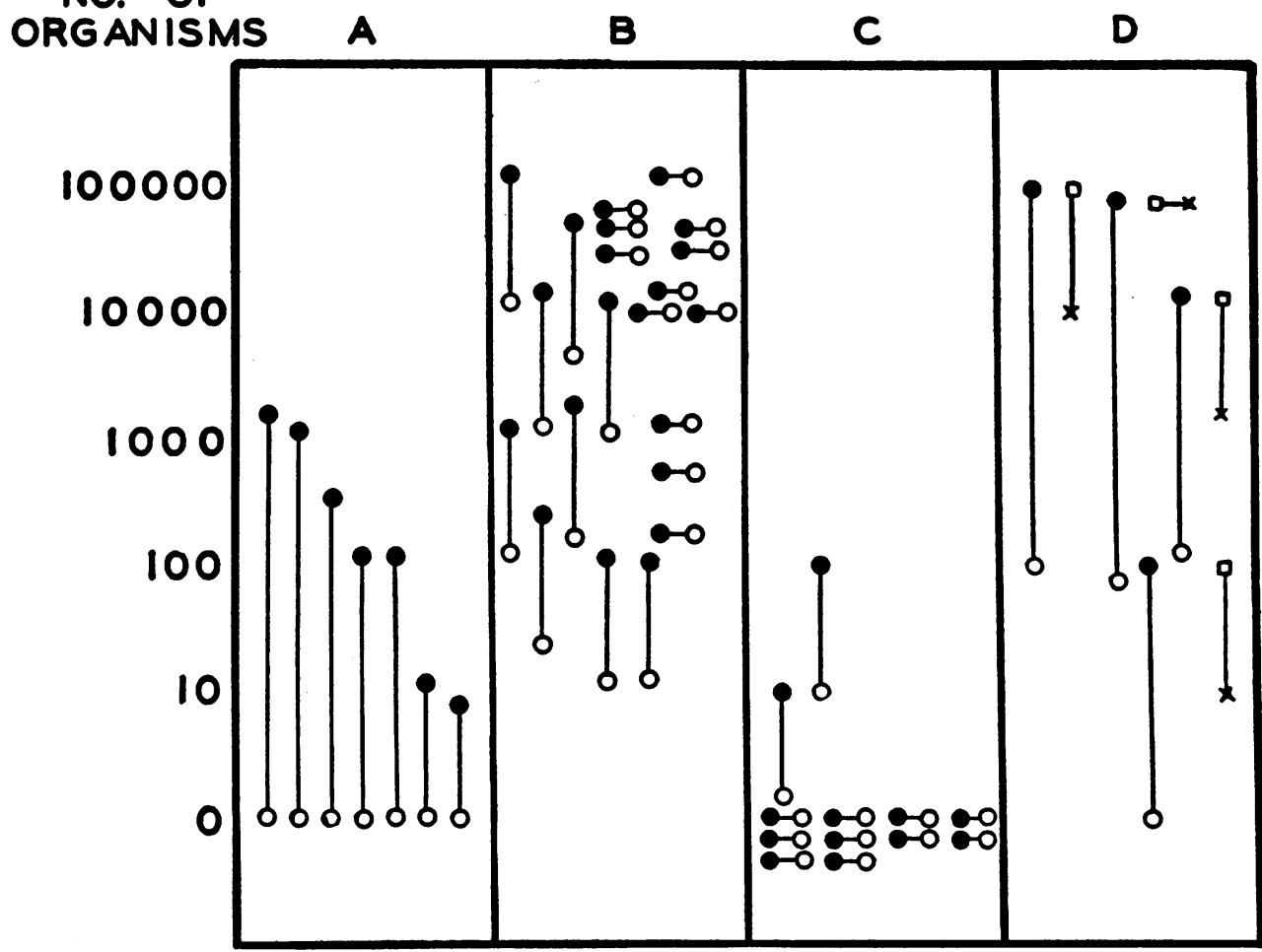

Fig. 1. Comparison of the Bacteriolytic Power of Whole Blood and Synovial Fluid

In Columns $\mathrm{A}, \mathrm{B}$, and $\mathrm{C}$ the dots indicate the maximum number of organisms killed by $0.5 \mathrm{cc}$. of whole blood. The circles indicate the maximum number killed by $0.5 \mathrm{cc}$. of synovial fluid. In Column D the solid dots and the squares indicate the maximum number of organisms killed by $0.5 \mathrm{cc}$. of whole blood, the circles the maximum number killed by $0.25 \mathrm{cc}$. of synovial fluid, and the crosses the maximum number killed by $0.5 \mathrm{cc}$. of synovial fluid. Column A-infected gonococcal synovial fluids. Column B-sterile gonococcal synovial fluids. Column Cnon-gonococcal sterile synovial fluids. Column D-sterile gonococcal synovial fluids. 
same individual contained antibodies, but in most instances the antibody titer of the blood was low. This probably accounted in part for the infected fluid, namely, that there was a very low antibody response at the time of the examination, and for this reason organisms were able to grow freely in the synovial fluid.

Sterile synovial fluid in gonococcal arthritis. There were 21 samples of sterile synovial fluid from patients with gonococcal arthritis, and the results of comparing the blood and synovial fluid in these cases are recorded in Figure $1-B$. In 12 of the 21 samples, the bactericidal titer of the whole blood and the synovial fluid was the same. In 9 , there was a tenfold difference in favor of the blood. This indicates that when $0.5 \mathrm{cc}$. of fluid is used there is either no demonstrable difference in the bactericidal power of the synovial fluid and the blood or, if there be a difference, it is very slight.

When $0.25 \mathrm{cc}$. of synovial fluid was used instead of $0.5 \mathrm{cc}$. it was found that the bactericidal power was always less with the $0.25 \mathrm{cc}$. than with $0.5 \mathrm{cc}$. (Figure 1-D). When equivalent amounts of synovial fluid and plasma are used, provided the amount is small, the blood usually shows a somewhat higher bactericidal power than the synovial fluid. The possible explanation for this difference will be discussed in the following paper (10).

Controls. For controls, we studied the blood and synovial fluid from individuals with rheumatic fever and rheumatoid arthritis. The results are shown in Figure 1-C. The blood of 10 of the patients was unable to kill any gonococci, but $0.5 \mathrm{cc}$. of the synovial fluids was able to kill 10 or less. These observations indicate that the synovial fluid in non-gonococcal arthritis is not bactericidal for the gonococcus.

These observations show that antibacterial antibodies for the gonococcus pass from the blood into the synovial cavities. When the synovial fluid is infected, the titer of the antibodies in the blood is comparatively low, whereas when the synovial fluid is sterile the antibody content of the blood is generally higher. When $0.5 \mathrm{cc}$. of fluid was used, the antibody content of the whole blood and synovial fluid was usually the same, but when
$0.25 \mathrm{cc}$. of synovial fluid was used the titer of antibodies was always lower.

In view of the difference in the bactericidal power of the blood and synovial fluid in some cases, it was necessary to determine whether these differences were due to the lack of complement or to the presence of other substances, such as mucin, since one essential difference between blood plasma and synovial fluid is the occurrence of mucin in the latter. The influence of mucin on the bactericidal action of the gonococcus will be taken up in the succeeding paper (10).

\section{Comparison of complement titer of blood and} synovial fluid in gonococcal arthritis

As related above, it was demonstrated previously that complement was necessary for specific bacteriolysis of the gonococcus. To determine whether complement was present in synovial fluid in the same or in different amounts as in the blood serum, it was titrated in both the blood and synovial fluid from the same patient. The results are presented in Table II. In general, it may be said that complement occurs in the synovial fluid in gonococcal and other types of

TABLE II

Comparison of the complement titer in the blood and synovial fluid of patients with gonococcal arthritis

\begin{tabular}{|c|c|c|}
\hline $\begin{array}{l}\text { Specimen } \\
\text { number }\end{array}$ & Blood & $\begin{array}{l}\text { Synovial } \\
\text { fluid }\end{array}$ \\
\hline & $c c$ & $c c$. \\
\hline \multicolumn{3}{|c|}{ INFECTED FLUIDS } \\
\hline $\begin{array}{l}1 \\
2 \\
3 \\
4 \\
5 \\
6 \\
7\end{array}$ & $\begin{array}{l}.04 \\
.02 \\
.03 \\
.04 \\
.07 \\
.04 \\
.03\end{array}$ & $\begin{array}{l}.03 \\
.20 \\
.06 \\
.06 \\
.30 \\
.08 \\
.20\end{array}$ \\
\hline \multicolumn{3}{|c|}{ STERILE FLUIDS } \\
\hline $\begin{array}{r}1 \\
2 \\
3 \\
4 \\
5 \\
6 \\
7 \\
8 \\
9 \\
10\end{array}$ & $\begin{array}{l}.03 \\
.04 \\
.03 \\
.02 \\
.03 \\
.08 \\
.06 \\
.05 \\
.02 \\
.04\end{array}$ & $\begin{array}{l}.06 \\
.06 \\
.06 \\
.04 \\
.02 \\
.07 \\
.08 \\
.06 \\
.03 \\
.03\end{array}$ \\
\hline \multicolumn{3}{|c|}{ NON-GONOCOCCAL STERILE FLUIDS } \\
\hline $\begin{array}{l}1 \\
2 \\
3 \\
4\end{array}$ & $\begin{array}{l}.02 \\
.07 \\
.04 \\
.04\end{array}$ & $\begin{array}{l}.04 \\
.06 \\
.03 \\
.03\end{array}$ \\
\hline
\end{tabular}


arthritis, and the titer of the complement in the blood and synovial fluid is approximately the same. In some of the infected fluids the complement titer of the synovial fluid was lower than that of the blood. It can not be said, however, that the lack of complement was responsible for an infected fluid, since sometimes it was present in the same amount as in the blood and it was never absent. It would appear that any difference that exists between the bactericidal action of the blood and synovial fluid must depend upon the amount of antibody present or the presence of substances that interfere with the action of the antibody.

\section{COMMENT}

The above observations indicate that antibodies diffuse from the blood plasma into the synovial cavities. When the synovial fluid was infected, the antibody content of the blood was low. When the synovial fluid was sterile, there were antibodies present in both the blood and synovial fluid. When the titer of antibodies was compared, it was found that they were the same or lower in the synovial fluid than in the blood. This difference in the titer could not be accounted for by the lack of complement, but it was suggestive that the presence of mucin in some way interfered with the action of antibody.

We believe that the present evidence explains the presence of a sterile synovial fluid in many cases of gonococcal arthritis, namely, that the fluid is sterile because the titer of antibodies in the synovial fluid is high and the organisms that get into the cavities of the joints are rapidly destroyed. From the histological study of the synovial tissues in gonococcal arthritis, it was suggested that the presence of organisms in fluids might be explained on a basis of an extension of the bacteria from the periarticular and subsynovial tissues into the cavity of the joints after they had destroyed the synovial membrane; whereas the sterility of fluids might be explained in part on the basis that the synovial membrane was intact and the inflammation confined for the most part to the subsynovial tissues. It would appear, then, that the sterility of synovial fluid depends upon a favorable balance between the antibody response, the degree of inflammation, and the number of infecting organisms.

\section{SUMMARY AND CONCLUSIONS}

From a comparative study of the bactericidal activity of the blood and synovial fluid in gonococcal arthritis and in arthritis due to other causes, the following conclusions are justified.

Synovial fluid in non-gonococcal arthritis is not bactericidal for the gonococcus. This is due to the absence of demonstrable antibodies against the gonococcus, and not due to the absence of complement.

Synovial fluids which are infected with gonococci fail to show active bactericidal antibodies. The blood from such individuals is often actively bactericidal for the homologous organism.

When the synovial fluid which is obtained from cases of gonococcal arthritis is sterile, it is actively bactericidal for the homologous strain of gonococcus. This is due to the presence of antibody and complement.

Heating synovial fluid at $56^{\circ} \mathrm{C}$. for 30 minutes destroys its bactericidal activity. This is dependent upon inactivation of complement and not due to the destruction of antibody.

When the bactericidal activity of synovial fluid and whole blood is compared in the same patient, using the homologous organism, it is found that when the synovial fluid is infected, the bactericidal content of the blood is higher than the synovial fluid. When the synovial fluid is sterile the bactericidal content is the same or slightly less than the blood.

\section{BIBLIOGRAPHY}

1. Myers, W. K., Keefer, C. S., and Holmes, W. F., Jr., The characteristics of synovial fluid in gonococcal arthritis. J. Clin. Invest., 1934, 13, 767.

2. Spink, W. W., and Keefer, C. S., Studies of gonococcal infection. II. The bacteriolytic power of the whole defibrinated blood of patients with gonococcal arthritis. J. Clin. Invest., 1937, 16, 177.

3. Spink, W. W., and Keefer, C. S., Studies of gonococcal infection. I. A study of the mode of destruction of the gonococcus in vitro. J. Clin. Invest., 1937, 16, 169.

4. Gordon, J., and Hoyle, L., The bactericidal action of serum against meningococcus, gonococcus and Micrococcus catarrhalis. J. Path. and Bact., 1936, 43, 537.

Further observations on the general bactericidal action of normal serum. Ibid., 1936, 43, 545. 
5. Finland, M., Immunological reactions of pneumonic pleural fluids. J. Exper. Med., 1932, 55, 169.

6. Zia, S. H., The occurrence of dysentery and typhoid antibodies in joint and pleural exudates. Nat. M. J. China, 1931, 17, 302.

7. Labor, M., and von Balogh, E., Zytologische und serologische Untersuchungen der Synovia im besonderen bei akuten Gelenksentzündungen. Wien. klin. Wchnschr., 1919, 32, 535.

8. Longcope, W. T.-Quoted by Boots, R. H., and
Swift, H. F., The arthritis of serum sickness. J. A. M. A., 1923, 80, 12.

9. Holmes, W. F., Jr., Keefer, C. S., and Myers, W. K., Antitryptic activity of synovial fluid in patients with various types of arthritis. J. Clin. Invest., $1935,14,124$.

10. Keefer, C. S., and Spink, W. W., Studies of gonococcal infection. IV. The effect of mucin on the bacteriolytic power of whole blood and immune serum. J. Clin. Invest., 1937, 16, 23. 